\title{
Assessment of Ecosystem Services and Capabilities of Communities from different Scales and Niches - Implications on Sustainability Goals
}

\author{
Padhmanand Sudhakar ${ }^{1 \star}$
}

${ }^{1} 3$ Greyfriars Road, NR1 1PR, Norwich, UNITED KINGDOM

*Corresponding Author: padbiogermany@gmail.com

Citation: Sudhakar, P. (2020). Assessment of Ecosystem Services and Capabilities of Communities from different Scales and Niches - Implications on Sustainability Goals. European Journal of Sustainable Development Research, 4(3), em0122. https://doi.org/10.29333/ejosdr/7843

\begin{abstract}
ARTICLE INFO
Received: 1 Sep. 2019

Accepted: 20 Feb. 2020

ABSTRACT

Ecosystems are complex compendia of biotic and abiotic components and characterized by exchanges of energy and mass. Via the actions and functions of the resident components which assemble into communities, ecosystems provide both direct/indirect tangible and intangible services to human society as well as the natural world. This holds true for ecosystems which cut across various scales and niches. Various frameworks have been devised to categorize and evaluate the services provided by ecosystems and/or their components. In this study, the services elicited by three specific communities occupying different ecosystem niches and having distinct scalar resolution are assessed. Firstly, the microbial communities which reside in the mammalian gut ecosystem, the microbial communities in the soil and the indigenous/local communities who inhabit the ecosystems comprising their traditional landscapes. Further, the roles and functions of these diverse communities, separated by scale and mostly and largely contributing to the homeostasis and functionality of their corresponding ecosystems, are evaluated. The services rendered by these communities are then mapped to the United Nations Sustainable Development Goals. Finally, the importance of these communities in maximizing social, economic and ecological capital is pointed out.
\end{abstract}

Keywords: communities, gut microbiota, soil microbiota, indigenous/local communities, ecosystem services, sustainable development goals, social, ecological, economic capital

\section{INTRODUCTION}

Across various scales, communities render important functions to their ecosystems which in turn may be part of larger entities such as higher-organisms, landscapes, water bodies etc. The functionalities are primarily the result of synergistic interactions mediated by the components of these communities with other biotic or abiotic components (Blair et al., 2000). These functionalities result in services for human society and well-being. Hence, it is imperative that decision making by societies, businesses and governments take into account the services provided by ecological communities (Daily et al., 2009).

To assess and evaluate the services provided by ecosystems and their components, several frameworks have been proposed. The Economics of Ecosystems and Biodiversity (TEEB)(http://www.teebweb.org/) is a global initiative which provides a descriptive framework to capture, assign value and assess the functions rendered by nature. The framework thereby enables the mainstreaming of ecosystem services (ES) into decision making and policy. The TEEB framework has been widely applied to various ecosystems and contexts as a tool to support decision makers in charge of policy portfolios affecting the environment and natural resources.

To demonstrate the applicability of this approach, three different ecosystems from different dimensions of scale are selected and a non-exhaustive list of ecosystem services provided by these communities is assessed. As examples of communities in ecosystems at a micro-scale, the microbial communities of the mammalian gut and the soil are chosen. At the macro-scale, indigenuous and local communities (ILCs) who inhabit various landscapes are chosen. As for the ILCs, the known capabilities (Sangha \& Russell-Smith, 2017; Sangha et al., 2018) of the ILCs as a result of their long-term relationships with their ecosystems are enlisted. Such capabilities of the ILCs have been demonstrated to be useful in dealing with ecological restoration (Reyes-García et al., 2019) and managing ecosystems for the purposes of conservation (Benyei et al., 2019; Reyes-García \& Benyei, 2019) in addition to contributing to the well-being of the ILCs themselves (Freeman, 2019; Sangha et al., 2015).

The empirically distant communities were chosen in this study in order (a) to demonstrate the applicability of the ES framework in compiling integrated policy paradigms aimed at improving public health and environmental sustainability in a 
Table 1. Some of the ecosystem services provided by the gut microbiota, categorized according to the modified (addition of indicator functions) TEEB classification of ecosystem services

\begin{tabular}{|c|c|}
\hline $\begin{array}{l}\text { Provisioning functions } \\
\text { - Production of short chain fatty acids } \\
\text { - } \text { Synthesis of vitamins } \\
\text { - } \text { Digestion of proteins } \\
\text { - Metabolism of polyphenols }\end{array}$ & $\begin{array}{l}\text { References } \\
\text { (Muñoz-Tamayo et al., 2011; Wang et al., 2014) } \\
\text { (Gustafsson et al., 1962; Magnúsdóttir et al., 2015) } \\
\text { (Dai et al., 2013; Smith and Macfarlane, 1996) } \\
\text { (Clavel et al., 2006; Russell et al., 2008; Tomas-Barberan et al., 2014) }\end{array}$ \\
\hline $\begin{array}{l}\text { Regulating functions } \\
\text { - Maintaining gut barrier integrity } \\
\text { - Glucose homeostasis } \\
\text { - Warding off pathogens } \\
\text { - Controlling obesity } \\
\text { - Role in cardiovascular diseases } \\
\end{array}$ & $\begin{array}{l}\text { References } \\
\text { (Hiippala et al., 2018) } \\
\text { (De Vadder et al., 2014; Tolhurst et al., 2012) } \\
\text { (Jacobson et al., 2018; Kamada et al., 2013) } \\
\text { (Cani et al., 2008; Gao et al., 2018); } \\
\text { (Chan et al., 2016; Li et al., 2017; Stepankova et al., 2010) }\end{array}$ \\
\hline $\begin{array}{l}\text { Supporting functions } \\
\text { - Modulation of bile acid properties } \\
\text { - } \text { Priming the host immune system } \\
\text { - } \text { Reducing gut inflammation and related diseases } \\
\text { - Neo-natal and early-life development }\end{array}$ & $\begin{array}{l}\text { References } \\
\text { (Gustafsson et al., 1977; Jones et al., 2008; Van Eldere et al., 1996) } \\
\text { (Ohnmacht et al., 2015) } \\
\text { (Laval et al., 2015; Nishida et al., 2018; Pascal et al., 2017; Sun et al., 2019) } \\
\text { (Dzidic et al., 2018; Ficara et al., 2018; Zhuang et al., 2019) }\end{array}$ \\
\hline $\begin{array}{l}\text { Cultural functions } \\
\text { - Psychological well-being via the gut-brain axis } \\
\text { - Relational value }\end{array}$ & $\begin{array}{l}\text { References } \\
\text { (Bonfili et al., 2017; Bravo et al., 2011; Kennedy et al., 2017; McVey Neufeld et al., 2015) } \\
\text { - }\end{array}$ \\
\hline $\begin{array}{l}\text { Indicator functions } \\
\text { Indicator of healthy and disease states }\end{array}$ & $\begin{array}{l}\text { References } \\
\text { (Armour et al., 2019; Ren et al., 2019; Wirbel et al., 2019) }\end{array}$ \\
\hline
\end{tabular}

contiguous manner, (b) to showcase the need for tailored and contextually-relevant frameworks evaluating ecosystem services and services to ecosystems and (c) to bridge the gap between different groups of ES researchers embedded in diverse epistemological contexts. By mapping the ESs provided by the chosen communities to the 17 Sustainable Development Goals set by the United Nations, it is posited that the functions imparted by these communities contribute to social, economic and ecological capital.

\section{SELECTING THE ECOSYSTEMS AND COMMUNITIES}

Microbial communities comprising a mixture of bacteria, viruses, fungi etc and differing in composition and abundance reside in the ecosystems of both the gut and the soil. While gut microbial communities have an important influence on human health/disease (Sánchez et al., 2017), previous research has shown how molecular components of the mammalian gut are involved in mediating homeostatic functions (Jones et al., 2018) as well as interacting with microbial proteins (Sudhakar et al., 2019). In a similar manner, the microbial communities in the soil are central to several key services which are not only key to agriculture and food production (Jacoby et al., 2017) but also in several other critical processes.

However, the ILCs were chosen for a different set of reasons which relate to a range of factors. These include the existential threats faced by these communities (Begotti \& Peres, 2019) and the relevance of these human communities in combating global challenges such as climate change and biodiversity loss (Etchart, 2017). Many of these capabilities are based on diverse knowledge systems which give rise to a sense of stewardship (Bennett et al., 2018) and a set of socio-ecological values which arise as a result of the relationships forged between human beings and nature (Neeganagwedgin, 2013). Interestingly, the capabilities imparted on ILCs include ecological knowledge which empower them to take care of their immediate ecosystems. The ecological knowledge also helps contribute to initiatives focussed on mitigating climate change and biodiversity loss (Benyei et al., 2019). Hence, the example of ILCs and their capability functions is expected to increase the awareness of ILCs and their ecological importance among natural scientists in the Western world.

The aforementioned communities in this study were chosen due to one other overarching reason - the possibility offered by the application of systems thinking (Williams et al., 2017) to reveal their interconnectedness (Table 1). As an example, Western diets are known to have negative impacts on gut microbial communities which dispose the affected individuals to a plethora of modern diseases (Telle-Hansen et al., 2018). As a result, researchers have started to study the gut microbial communities of ILCs as a means of discovering new knowledge and practices such as diet for restoring gut health (Stagaman et al., 2018). The traditional knowledge of ILCs in managing their ecosystems including the soils (Rajasekaran \& Warren, 1995) need to be acknowledged and evaluated. At the same time, there is a long-standing paradigm in which the ILCs have bore the brunt of Western influences. This happens directly or indirectly via habitat destruction, violation of land rights etc which threaten the very existence of the ILCs (Begotti \& Peres, 2019). Hence, the issue of ILCs need to be highlighted both from the perspective of opportunities and threats. 
Table 2. Some of the ecosystem services provided by the soil microbiota, categorized according to the modified (addition of indicator functions) TEEB classification of ecosystem services. * denote marketable services

\begin{tabular}{|c|c|}
\hline $\begin{array}{l}\text { Provisioning functions } \\
\text { - } \quad \text { Freshwater provision } \\
\text { - } \quad \text { Produce (food, fiber, timber, clay) } \\
\text { - } \quad \text { Bioactive compounds and genetic resources }{ }^{*}\end{array}$ & $\begin{array}{l}\text { References } \\
\text { (Grenni et al., 2009) } \\
\text { (Trivedi et al., 2017) } \\
\text { (Martín and Liras, 2019) }\end{array}$ \\
\hline $\begin{array}{l}\text { Regulating functions } \\
\text { - } \quad \text { Control of pathogens, pests and diseases } \\
\text { - } \quad \text { Remediation of soils and plants from toxins and pollutants } \\
\text { - } \quad \text { Prevention of antibiotic resistance genes' accumulation } \\
\text { - } \quad \text { Cycling, fixation and bioavailability of nutrients in the soil } \\
\text { - Plant health and immunity } \\
\text { - } \quad \text { Transformation of organic matter } \\
\text { - Chelation of metals }\end{array}$ & $\begin{array}{l}\text { References } \\
\text { (Blaya et al., 2016) } \\
\text { (Dang et al., 2019; Lladó et al., 2017; Simonin et al., 2017; Xu et al., 2017) } \\
\text { (Li et al., 2019) } \\
\text { (Pérez-Valera et al., 2019) } \\
\text { (Tang et al., 2019) } \\
\text { (Chialva et al., 2018; Kong et al., 2019; Yu et al., 2019) } \\
\text { (Cui et al., 2019; Fernández-Bayo et al., 2019; Li et al., 2018) } \\
\text { (Jones et al., 2019; Mesa et al., 2017) }\end{array}$ \\
\hline $\begin{array}{l}\text { Supporting functions } \\
\text { - Provides physical and biochemical medium/components for plant } \\
\text { growth, flowering etc } \\
\text { - Supporting the soil microbial communities including earthworms } \\
\text { etc } \\
\text { - Facilitates symbiosis between species (plant-bacteria, bacteria- } \\
\text { fungi etc) }\end{array}$ & $\begin{array}{l}\text { References } \\
\text { (Durán et al., 2018; Lu et al., 2018; Sui et al., 2019) } \\
\text { (Topalović and Heuer, 2019) } \\
\text { (Garrido-Oter et al., 2018; Gupta et al., 2019) }\end{array}$ \\
\hline $\begin{array}{l}\text { Cultural functions } \\
-\quad \text { Relational value } \\
\end{array}$ & References \\
\hline $\begin{array}{l}\text { Indicator functions } \\
\text { - Indicator of heavy metal pollution } \\
\text { - Indicator of plant health } \\
\text { - Indicator of nutrient availability and assimilation }\end{array}$ & $\begin{array}{l}\text { References } \\
\text { (Šrut et al., 2019) } \\
\text { (Köberl et al., 2017) } \\
\text { (Hermans et al., 2017) }\end{array}$ \\
\hline
\end{tabular}

\section{METHODOLOGY}

\section{Selection of Frameworks used for the Evaluation of Ecosystem Services and Capabilities}

The customary TEEB model (http://www.teebweb.org/) with the already established provisioning, regulating, supporting and cultural functions' categories with the addition of indicator functions is applied to assess and evaluate the services provided by microbial communities of the mammalian gut ecosystem and the soil ecosystem. With the aim of capturing the services provided by ILCs to ecosystems, the customized framework proposed by Combert et al. (2015) was used to enlist and categorize the different capabilities and functions of ILCS is applied.

\section{Literature Mining}

The evidence related to the functions and services of the communities were retrieved from Pubmed (until August 31, 2019) based on pairwise searches between two sets of keywords as follows. Set 1: gut microbiota, gut microbiome, soil microbiota, soil microbiome, indigenous populations, indigenous communities, indigenous and local communities. Set 2: functions, functionalities, roles, capabilities, services. The inferred functions and services of the communities based on the literature were categorized into various classes based on the TEEB model (regulating, provisioning, supporting, cultural and indicator functions) for the gut/soil microbiota and the service classes (protecting, enhancing, restoring and supporting based on Comberti et al 2015) for the ILCs respectively. Each of the functions and services were subsequently mapped manually to the corresponding sub-goals of the SDGs.

\section{RESULTS AND DISCUSSION}

\section{Assessment of Ecosystem Services and Capabilities of the Communities}

Using the frameworks described above, the services provided by the three chosen communities to their corresponding ecosystems were assessed and categorized (Tables 1-3). Decades of research on the mammalian gut microbial community has revealed its role in various functions which can be classified into the provisioning, regulating, supporting, cultural and indicator categories. From helping the host digest the food to enabling the absorption and assimilation of nutrients such as vitamins, short chain fatty acids, polyphenols, the gut microbiota elicits its functions via various mechanisms (see Table 1 for references). The gut microbiota also regulates and supports a variety of other processes in addition to providing nutrients to the host. These include a wide range of homeostatic functions such as warding off pathogens, maintaining the gut barrier integrity, priming the immune system and modulating the properties of bile acids. Unsurprisingly, the gut microbiota is either involved in the prevention of or associated with disorders such as cardiovascular disease, obesity, inflammatory bowel disease among others. Due to the recently discovered gut-brain axis, scientists have also discovered the role of the microbiota in cognition and psychological well-being thus 
Table 3. Some of the services provided by Indigenous and Local Communities (ILCS) and ILC knowledge as evaluated by the "Services to Ecosystems" framework proposed by (Comberti et al., 2015). * denote marketable services

\section{Protecting services}

- Prevent landscape change

- Information on keystone species

- Imparting protection based on sense of place attributes

- Ritual regulations and cultural prohibitions

\section{References}

(Horiuchi et al., 2011)

(Garibaldi and Turner, 2004; Wangpakapattanawong et al., 2010)

(Cuerrier et al., 2015; Lepofsky et al., 2017)

(Angsongna et al., 2016; Colding and Folke, 1997; Foin and Davis, 1984; Rappaport, 1967; Spangenberg et al., 2014)

\section{Enhancing services}

- Soil enrichment using biomass recycling

- Diversity enhancing and climate change mitigating anthropogenic burning

- Diverse practices to maintain grassland productivity and function

- Interplanting to increase species diversity in forests

- Maintaining fish stocks

- Manage ecosystem succession

- Combat climate change via carbon sequestration*

- Prevent desertification

- Trait modification and selection

- Transplantation and relocation

- Seed dispersal

Restoring services

- River restoration

- Restoration of mangroves and wetlands

- Restoration of lakes

- Restoring forests and watersheds

- Diverse approaches to restore mountain landscapes

- ILC knowledge as baseline sources for informing restoration targets (Eckert et al., 2017; Mustonen, 2013; Storm and Shebitz, 2006)

- Restore population of particular species

- Monitoring restoration of ecosystems

\section{Supporting services}

- Inclusion of cultural practices

- Enhancing cultural-ecological integrity

- Serving as repositories of knowledge thus contributing to human capital

\section{References}

(Solomon et al., 2016)

(Russell-Smith et al., 2015; Shaffer, 2010; Storm and Shebitz, 2006;

Trauernicht et al., 2015)

(Babai and Molnár, 2014; Stenseke, 2009)

(Ford and Nigh, 2015)

(Thornton et al., 2015)

(Diemont and Martin, 2009; Douterlungne et al., 2008)

(Salick et al., 2014)

(Macharia, 2004)

(Balée and Erickson, 2006)

(Erickson, 2010)

\section{References}

(Fox et al., 2017)

(Selvam et al., 2003)

(Coombes, 2007)

(Clement and Amezaga, 2009; Douterlungne et al., 2008; Paudyal et al., 2015; Wangpakapattanawong et al., 2010)

(Long et al., 2003)

(Hansson 2001) (Danielsen et al., 2013; Hartoyo et al., 2016)

\section{References}

(Cuerrier et al., 2015; Lepofsky et al., 2017; Russell-Smith et al., 2015)

(Sangha et al., 2015; Sangha et al., 2018)

(Benyei et al., 2019; Kelbessa, 2013; Reyes-García and Benyei, 2019)
(Shepard and Ramirez, 2011)

giving rise to cultural benefits and functions. Since changes in gut microbial compositions are associated with transition to disease states, the gut microbial communities also serve as indicators of disease development and progression. Unfortunately, none of the ESs provided by the gut microbiota could be categorized as marketable and there exists no Basic Value Transfer models/measures to even assign valuation to the non-marketable ESs.

Similarly, the soil microbiota elicits a plethora of functions (Table 2) to different constituents of the ecosystem, in which it is embedded in. These include direct provisional functions such as novel bioactive compounds and indirect provisional functions which serve to provide fuel, timber, produce via plants and trees which are nourished by the soil microbiota. Due to its interactions with a large number of other biotic and abiotic entities, the soil microbiota is at the helm of a large number of regulating and supporting functions (see Table 2 for references). These range from controlling nutrient cycling and making nutrients available to plants and facilitating symbiotic relationships involving plants, fungi to name a few. With respect to indicator functions, soil microbial compositions are used as markers for plant health and heavy metal pollution. The ESs are made up of two marketable ESs include "Carbon sequestration and regulation of green-house emissions" and "Bioactive compounds and genetic resources" with the rest belong to the non-marketable category. Provisioning and Regulating ESs of the non-marketable variety can be monetized using Basic Value Transfer (BVT) figures from other studies performed in similar contexts while Well-Being valuation methods can be used for the Cultural ESs.

In contrast to the gut and soil microbial communities whose ecosystem services were mostly assessed in terms of their contributions to human well-being, the role of the indigenous and local communities (ILCS) were categorized based on a "service to ecosystems" framework put forward by (Comberti et al., 2015). The framework lets researchers put the perspective back on the ILCs and the services they render to ecosystems to be classified into four distinct types: protecting, enhancing, restoring and supporting. As can be gleaned from Table 3, ILCs and their knowledge have been used in various contexts to either maintain or restore the functionality of ecosystems. In the current context where human society is encountering the hard truths of ecological degradation, exploitation of natural resources, loss of biodiversity and climate change, the roles played by ILCs become all the more prominent due to the fact that ILCs reside in biodiverse areas with huge future potential for carbon sequestration (see Table $\mathbf{3}$ for references). In general, ILCs also have a huge incentive to protect such areas since it is the very same areas from which the either derive their livelihood and/or cultural benefits. ILCs not only protect and maintain their ecosystems using adaptive knowledge and cultural practices (Table 3) but also contribute either on their own or in collaboration with other like-minded agencies to restore degraded ecosystems like lakes, mangroves and forests. The adaptive knowledge of ILCs can be exemplified for example by their know-how on keystone species, planting strategies, biomass recycling, ecosystem succession, soil fertility among others. Furthermore, with their cultural practices, ritual prohibitions and reverence for cultural keystone places, they also 
Table 4. Mapping ecosystem services and services to ecosystems rendered by the gut/soil microbial communities and ILCS respectively to the UN Sustainable Development Goals. Details on how the ESs map and services to ecosystems map to the subgoals can be found in Supplementary File 1

\begin{tabular}{|c|c|c|c|}
\hline SDG & Gut microbiota & Soil microbiota & ILCs \\
\hline \multicolumn{4}{|l|}{ No poverty } \\
\hline \multicolumn{4}{|l|}{ Zero hunger } \\
\hline \multicolumn{4}{|l|}{ Good health and well-being } \\
\hline \multicolumn{4}{|l|}{ Quality education } \\
\hline \multicolumn{4}{|l|}{ Gender equality } \\
\hline \multicolumn{4}{|l|}{ Clean water and sanitation } \\
\hline \multicolumn{4}{|l|}{ Affordable and clean energy } \\
\hline \multicolumn{4}{|l|}{ Decent work and economic growth } \\
\hline \multicolumn{4}{|l|}{ Industry, innovation \& infrastructure } \\
\hline \multicolumn{4}{|l|}{ Reduced inequalities } \\
\hline \multicolumn{4}{|l|}{ Sustainable cities and communities } \\
\hline \multicolumn{4}{|l|}{ Responsible consumption \& production } \\
\hline \multicolumn{4}{|l|}{ Climate action } \\
\hline \multicolumn{4}{|l|}{ Life below water } \\
\hline \multicolumn{4}{|l|}{ Life on land } \\
\hline \multicolumn{4}{|l|}{ Peace, justice and strong institutions } \\
\hline Partnerships for the goals & & & \\
\hline
\end{tabular}

contribute to a sense of place and socio-ecological values which help conserve ecosystems. Thus, from diverse epistemological perspectives (Tengö et al., 2014), the activities and knowledge of ILCs service ecosystems to keep them functional. The only marketable ES for ILCs was identified as the "Combat climate change via carbon sequestration" via C-bonds by virtue of Payment for Ecosystem Service protocols.

\section{Contribution of Ecosystem Services Rendered by the Communities to the Sustainable Development Goals}

In order to relate the relevance of the chosen communities to macro-level perspectives, their services were mapped to the 17 Sustainable Development Goals (SDGs) proposed by the United Nations (Table 4, Supplementary Table 1). Due to its very specific niche, the gut microbiota particularly impacts the SDGs by its effect on the third goal of "Ensuring healthy lives and promotion of well-being for all at all ages". Of note, the gut microbiota is involved in the mammalian health and development at different life stages and is implicated in both maintaining health and when disrupted in mediating diseases. However, due to its impact on the health of human populations around the world, it is a major contributor to social capital and the opportunity costs of healthcare.

On the other hand, the soil microbiota because of its connections to a large number of biotic and abiotic components, could impact 13 of the 17 SDGs (Table 4, Supplementary Table 1). The ecosystem services of the soil microbiota could be mapped strongly to SDG2 ("End hunger, achieve food security and improved nutrition and promote sustainable agriculture"), SDG3 ("Ensure healthy lives and promote well-being for all at all ages"), SDG8 ("Promote sustained, inclusive and sustainable economic growth, full and productive employment and decent work for all"), SDG13 ("Take urgent action to combat climate change and its impacts"), SDG15 ("Protect, restore and promote sustainable use of terrestrial ecosystems, sustainably manage forests, combat desertification, and halt and reverse land degradation and halt biodiversity loss") among others thus contributing to social, ecological and economic capital.

The services provided by the ILCs to the ecosystems also displayed comparable mapping profiles with 12 SDGs linked to the services (Table 4, Supplementary Table 1). Although not surprising, the services of the ILCs and their knowledge could be mapped to prominent SDGs such as SDG13 ("Take urgent action to combat climate change and its impacts"), SDG14 ("Conserve and sustainably use the oceans, seas and marine resources for sustainable development"), SDG15 ("Protect, restore and promote sustainable use of terrestrial ecosystems, sustainably manage forests, combat desertification, and halt and reverse land degradation and halt biodiversity loss"), SDG12 ("Ensure sustainable consumption and production patterns") and SDG6 ("Ensure availability and sustainable management of water and sanitation for all"). However, it is noteworthy to mention that in addition to goals associated with various tangible components, the services of the ILCs could also contribute to cultural, educational and well-being aspects such as SDG 11.4 ("Strengthen efforts to protect and safeguard the world's cultural and natural heritage") and SDG 4.7 ("By 2030, ensure that all learners acquire the knowledge and skills needed to promote sustainable development, including, among others, through education for sustainable development and sustainable lifestyles, human rights, gender equality, promotion of a culture of peace and non-violence, global citizenship and appreciation of cultural diversity and of culture's contribution to sustainable development"). The ILCs thus via their services positively influence social, ecological and economic capital.

\section{DRAWBACKS OF THE STUDY}

\section{Negative Functions of Communities are Ignored}

Although ESs in the traditional sense refer to positive benefits rendered to human beings, services which impart negative effects have also been reported (Li et al., 2014; Power, 2010; Shackleton et al., 2016). For instance, the gut as well as the soil 
microbiota is a reservoir of antibiotic resistance genes (Baron et al., 2018; Hu et al., 2013; Relman \& Lipsitch, 2018). There has been widespread debates and criticisms on the categorization of negative functions (Shapiro \& Báldi, 2014; Villa et al., 2014). However, the negative functions and the uncertainties which they could putatively elicit are a cause for concern.

\section{No Context Specificity}

The ESs assessed in this study for all three communities were based on evidence collected from studies conducted all over the world. In other words, the assessment is very generalized without any specificity in terms of context such as socio-cultural phenomena (Everard et al., 2018; van Riper et al., 2017) or site-specific information while the ESs are interpreted collectively. While the approach can be applicable to specific contexts, the results in the study cannot be interpreted beyond generalities. This drawback also meant that scenario building and projection could not be performed.

\section{Qualitative Nature of the Assessment}

Due to the non-contextuality of the assessment, quantitative measures for example related to assigning values to the BVT for a bunch of services could not be performed since these could be different based on the region/country in which the evidence corresponding to the ES was reported.

\section{Inter-dependencies among Services, Capacities and Capabilities Ignored}

ESs seldom occur in isolation and are usually inter-dependent either based on direct/indirect mechanistic evidence or observed associations. For instance, the ability of the gut microbiota to produce short chain fatty acids is linked to maintenance of the gut barrier integrity via mechanistic effects (Mörkl et al., 2018; Morrison \& Preston, 2016; Parada Venegas et al., 2019). Facilitation of symbiotic relationship by the soil microbiota is closely linked to plant health and immunity as well as the control of pathogens (Harman \& Uphoff, 2019; Vannier et al., 2019). Also, quantitative information about the capacity allocation of the communities for various inter-dependent ESs is lacking and hence such information has also not been included in the study. In addition to the existence of such inter-dependencies among a plethora of ESs, there is an added degree of complexity in the case of ILCs. ILCs have complex relationships with their ecosystems as exhibited by the services they impart to the ecosystems. In addition, they provide well-being benefits and capability functions which are imparted to the ILCs as a result of such interactions (Sangha \& Russell-Smith, 2017; Sangha et al., 2015, 2018). Such intricate relationships in the domain of socio-ecological interactions at the backdrop of complex knowledge systems and behavioural sciences have not been considered in the study.

\section{IMPLICATIONS FOR SCIENCE, POLICY AND INDUSTRY}

\section{Gut Microbiota}

As demonstrated based on evidence from literature (Table 1), the gut microbiota contributes both to the physical and mental well-being of humans thus contributing to human capital. Recent research has also demonstrated that exposure to routinely used medicaments and therapeutics (Forslund et al., 2015), xenobiotic agents (Liang et al., 2019) present either in the food or other products also affect the gut microbial composition, sometimes (Chassaing et al., 2017) tipping it over to diseased states. From a product efficacy perspective, especially in the case of therapeutics, the gut microbiota has the potential to metabolize and alter the intended activity or absorption of therapeutic molecules (Enright et al., 2016). Thus, the gut microbiota is not only affected by its exposure to substances (such as therapeutics, xenobiotics and agents in the food) but also determine their metabolism, toxicity and efficacy. In the above discussed contexts, corporations and industries, especially in the food, pesticide/fertilizer and pharmaceutical sector need to be more cognizant of gut microbiota-mediated ill-effects or the non-beneficial/harmful effects on the gut microbiota upon exposure to compounds in their products. In tune with this, an increasing number of clinical trials have started to investigate the gut microbiota as part of their efficacy and safety norms. However, this needs to become a widespread practice (in clinical trials or risk assessment protocols) in the pharmaceutical, food and pesticide/fertilizer sectors globally so as to enhance product quality from a consumer safety point of view. This requires policy level legislative and regulatory frameworks to be put in place to enforce the altered safety and risk assessment protocols.

\section{Soil Microbiota}

The soil microbiota is demonstrated to have a wide range of ESs (Table 2) even based on our limited assessment and hence is bound to have far-reaching impacts arising from different anthropogenic activities and natural events - directly and/or indirectly. While it is out of the scope of this study to outline all the possible drivers which affect the soil microbiota, the most important ones which have a heavy-footprint, need prioritization in terms of research and where legislation needs to be enacted, are identified. Among other factors, the composition of the soil microbiota determines soil fertility and function in terms of its ability to support plant health by enhancing symbiotic relationships (Garrido-Oter et al., 2018; Gupta et al., 2019) which not only promote productivity but also the nutrition of the produce.

Misinformed choices in the farming sector have led to the overuse and abuse of agricultural inputs such as fertilizers and pesticides which detrimentally impact the function and composition of the soil microbiota. Pesticide exposure not only results in depreciating the supporting and regulating ESs (Chowdhury et al., 2008) of the soil microbiota but also has unintended consequences on plant health (Mitra and Raghu, 1998) and resistance of pests/pathogens (Bagchi et al., 2016) thus impacting food security. Besides, fertilizers and pesticides also end up in the food-chain due to systemic bioaccumulation in the produce and runoffs into the water-bodies (Carvalho, 2017). Meanwhile, regenerative agriculture and its various forms (LaCanne \& Lundgren, 2018) 
have been shown to impart beneficial impacts on the soil microbiota by enriching its diversity (Hendgen et al., 2018) and thereby enhancing plant health and nutrition (Tsvetkov et al., 2018).

a. In light of the above, it is imperative to enact legislation, policy and research frameworks in order to improve the diversity of the soil microbiota and thereby the various ecosystem services provided by the soil microbiota. This could include, but not limited to Providing incentives for corporations to develop soil- and biodiversity-friendly compounds for use in agriculture

b. Harmonized documentation and research on best practices of soil management from across the globe

c. Enhanced risk assessment protocols to evaluate the unintended and off-target effects of pesticides and fertilizers, and ameliorate them

d. Payment for Ecosystem Service based tools and approaches to incentivize farmers adopting regenerative agriculture and its practices

e. Providing free certification for farmers practising regenerative agriculture and their produce or legislate communityreviewed peer-certification such as Participatory Guarantee Systems (Home et al., 2017; Montefrio \& Johnson, 2019)

\section{ILCs}

Despite their geographical, socio-cultural and epistemological separation from mainstream societies, the services of the ILCS to the SDGs are substantial (Tables 3-4) and hence need to be acknowledged scientifically, politically and economically. ILCs not only rely on their ecological habitats for sustenance but also derive the capabilities (as a result of their long-term interactions with their ecosystems) which enable them to provide services enhancing/restoring ecosystem functions (Reyes-García et al., 2019). In the above described context, conservation measures aimed at ecosystems in which ILCs reside need to go hand-in-hand with programmes geared towards ILC well-being, especially in scenarios where there are complex interactions between the ILCs and their ecosystems. Moreover, in the current global scenario which is characterized by heavy anthropogenic footprints on climate change, biodiversity loss and natural resource depletion, the knowledge and practices of the ILCs have huge potential in socioecological and human eco-dynamics research (Fitzhugh et al., 2018). As a response, science and policy measures need to be geared towards

a. Increased engagement and inclusion of ILCs in scientific research to discover new knowledge to manage ecosystems, biodiversity, soil health, gut health among others

b. Equitable recognition of ILCs in the proceeds and academic/economic benefits of intellectual property derived from ILC knowledge

c. Increased recognition and acknowledgement of alternative and parallel knowledge systems which are characteristic of ILC cultures and way of life

d. Enhanced protection of ILC habitats and ecosystems

e. Better provision and recognition of ILC rights and access to traditional lands and resources for sustenance, way of life, intergenerational education and cultural practices

\section{CONCLUSION}

By evaluating the services elicited by communities (gut microbiota, soil microbiota, and ILCs) representative of three different ecosystems from different scalar resolutions using customized frameworks and mapping them onto the SDGs proposed by the United Nations, the contribution of the communities to human, ecological and economic capital is demonstrated. Although not context specific and limited to qualitative assessments, it is evident that the gut microbiota, soil microbiota and the ILCs provide both material and cultural benefits to mainstream human societies as well as other components of the ecosystems. Examples of anthropogenic activities which disrupt the services provided by these communities are identified and recommendations to enhance/restore their capacities in providing the ecosystems functions are laid out. The assessment carried out in this study provide evidence to researchers and policy makers from multiple sectors to appreciate the services provided by distinct communities and how these services can be leveraged and harnessed to enhance human, ecological and social capital.

\section{REFERENCES}

Angsongna, A., Ato Armah, F., Boamah, S., Hambati, H., Luginaah, I., Chuenpagdee, R., \& Campbell, G. (2016). A systematic review of resource habitat taboos and human health outcomes in the context of global environmental change. Global Bioethics 27 , 91-111. https://doi.org/10.1080/11287462.2016.1212608

Armour, C. R., Nayfach, S., Pollard, K. S., \& Sharpton, T. J. (2019). A Metagenomic Meta-analysis Reveals Functional Signatures of Health and Disease in the Human Gut Microbiome. mSystems 4. https://doi.org/10.1128/mSystems.00332-18

Babai, D., \& Molnár, Z. (2014). Small-scale traditional management of highly species-rich grasslands in the Carpathians. Agriculture, Ecosystems \& Environment 182, 123-130. https://doi.org/10.1016/j.agee.2013.08.018

Bagchi, V. A., Siegel, J. P., Demkovich, M. R., Zehr, L. N., \& Berenbaum, M. R. (2016). Impact of pesticide resistance on toxicity and tolerance of hostplant phytochemicals in amyelois transitella (lepidoptera: pyralidae). J. Insect Sci. 16. https://doi.org/10.1093/jisesa/iew063 
Balée, W. L., \& Erickson, C. L. (2006). Time and complexity in historical ecology: studies in the neotropical lowlands. New York Chichester, West Sussex: Columbia University Press. https://doi.org/10.7312/bale13562

Baron, S., Diene, S., \& Rolain, J.-M. (2018). Human microbiomes and antibiotic resistance. Human Microbiome Journal 10, $43-52$. https://doi.org/10.1016/j.humic.2018.08.005

Begotti, R. A., \& Peres, C. A. (2019). Brazil's indigenous lands under threat. Science $363,592$. https://doi.org/10.1126/science.aaw3864

Bennett, N. J., Whitty, T. S., Finkbeiner, E., Pittman, J., Bassett, H., Gelcich, S., \& Allison, E. H. (2018). Environmental stewardship: A conceptual review and analytical framework. Environ. Manage. 61, 597-614. https://doi.org/10.1007/s00267-017-0993-2

Benyei, P., Arreola, G., \& Reyes-García, V. (2019). Storing and sharing: A review of indigenous and local knowledge conservation initiatives. Ambio. https://doi.org/10.1007/s13280-019-01153-6

Blair, J. M., Collins, S. L., \& Knapp, A. K. (2000). Ecosystems as Functional Units in Nature. Natural Resources \& Environment 14, 150155. Retrieved from https://www.jstor.org/stable/40923968?seq=1

Blaya, J., Marhuenda, F. C., Pascual, J. A., \& Ros, M. (2016). Microbiota characterization of compost using omics approaches opens new perspectives for phytophthora root rot control. PLOS ONE 11, e0158048. https://doi.org/10.1371/journal.pone.0158048

Bonfili, L., Cecarini, V., Berardi, S., Scarpona, S., Suchodolski, J. S., Nasuti, C., Fiorini, D., Boarelli, M. C., Rossi, G., \& Eleuteri, A. M. (2017). Microbiota modulation counteracts Alzheimer's disease progression influencing neuronal proteolysis and gut hormones plasma levels. Sci. Rep. 7, 2426. https://doi.org/10.1038/s41598-017-02587-2

Bravo, J. A., Forsythe, P., Chew, M. V., Escaravage, E., Savignac, H. M., Dinan, T. G., Bienenstock, J., \& Cryan, J. F. (2011). Ingestion of Lactobacillus strain regulates emotional behavior and central GABA receptor expression in a mouse via the vagus nerve. Proc Natl Acad Sci USA 108, 16050-16055. https://doi.org/10.1073/pnas.1102999108

Cani, P. D., Bibiloni, R., Knauf, C., Waget, A., Neyrinck, A. M., Delzenne, N. M., \& Burcelin, R. (2008). Changes in gut microbiota control metabolic endotoxemia-induced inflammation in high-fat diet-induced obesity and diabetes in mice. Diabetes 57, $1470-1481$. https://doi.org/10.2337/db07-1403

Carvalho, F. P. (2017). Pesticides, environment, and food safety. Food Energy Secur. 6, 48-60. https://doi.org/10.1002/fes3.108

Chan, Y. K., Brar, M. S., Kirjavainen, P. V., Chen, Y., Peng, J., Li, D., Leung, F. C.-C., \& El-Nezami, H. (2016). High fat diet induced atherosclerosis is accompanied with low colonic bacterial diversity and altered abundances that correlates with plaque size, plasma A-FABP and cholesterol: a pilot study of high fat diet and its intervention with Lactobacillus rhamnosus GG (LGG) or telmisartan in ApoE-/- mice. BMC Microbiol. 16, 264. https://doi.org/10.1186/s12866-016-0883-4

Chassaing, B., Van de Wiele, T., De Bodt, J., Marzorati, M., \& Gewirtz, A. T. (2017). Dietary emulsifiers directly alter human microbiota composition and gene expression ex vivo potentiating intestinal inflammation. Gut 66, $1414-1427$. https://doi.org/10.1136/gutjnl-2016-313099

Chialva, M., Zhou, Y., Spadaro, D., \& Bonfante, P. (2018). Not only priming: Soil microbiota may protect tomato from root pathogens. Plant Signal. Behav. 13, e1464855. https://doi.org/10.1080/15592324.2018.1464855

Chowdhury, A., Pradhan, S., Saha, M., \& Sanyal, N. (2008). Impact of pesticides on soil microbiological parameters and possible bioremediation strategies. Indian J. Microbiol. 48, 114-127. https://doi.org/10.1007/s12088-008-0011-8

Clavel, T., Henderson, G., Engst, W., Doré, J., \& Blaut, M. (2006). Phylogeny of human intestinal bacteria that activate the dietary lignan secoisolariciresinol diglucoside. FEMS Microbiol. Ecol. 55, 471-478. https://doi.org/10.1111/j.1574-6941.2005.00057.x

Clement, F., \& Amezaga, J. M. (2009). Afforestation and forestry land allocation in northern Vietnam: Analysing the gap between policy intentions and outcomes. Land use policy 26, 458-470. https://doi.org/10.1016/j.landusepol.2008.06.003

Colding, J., \& Folke, C. (1997). The relations among threatened species, their protection, and taboos. CE 1. https://doi.org/10.5751/ES-00018-010106

Comberti, C., Thornton, T. F., Wyllie de Echeverria, V., \& Patterson, T. (2015). Ecosystem services or services to ecosystems? Valuing cultivation and reciprocal relationships between humans and ecosystems. Global Environmental Change 34, $247-262$. https://doi.org/10.1016/j.gloenvcha.2015.07.007

Coombes, B. (2007). Defending community? Indigeneity, self-determination and institutional ambivalence in the restoration of Lake Whakaki. Geoforum 38, 60-72. https://doi.org/10.1016/j.geoforum.2006.05.006

Cuerrier, A., Turner, N. J., Gomes, T. C., Garibaldi, A., \& Downing, A. (2015). Cultural keystone places: conservation and restoration in cultural landscapes. J. Ethnobiol. 35, 427-448. https://doi.org/10.2993/0278-0771-35.3.427

Cui, Y., Fang, L., Deng, L., Guo, X., Han, F., Ju, W., Wang, X., Chen, H., Tan, W., \& Zhang, X. (2019). Patterns of soil microbial nutrient limitations and their roles in the variation of soil organic carbon across a precipitation gradient in an arid and semi-arid region. Sci. Total Environ. 658, 1440-1451. https://doi.org/10.1016/j.scitotenv.2018.12.289

Daily, G. C., Polasky, S., Goldstein, J., Kareiva, P. M., Mooney, H. A., Pejchar, L., Ricketts, T. H., Salzman, J., \& Shallenberger, R. (2009). Ecosystem services in decision making: time to deliver. Frontiers in Ecology and the Environment 7, 21-28. https://doi.org/10.1890/080025

Dai, Z.-L., Li, X.-L., Xi, P.-B., Zhang, J., Wu, G., \& Zhu, W.-Y. (2013). L-Glutamine regulates amino acid utilization by intestinal bacteria. Amino Acids 45, 501-512. https://doi.org/10.1007/s00726-012-1264-4 
Dang, C., Morrissey, E. M., Neubauer, S. C., \& Franklin, R. B. (2019). Novel microbial community composition and carbon biogeochemistry emerge over time following saltwater intrusion in wetlands. Glob. Chang. Biol. 25, 549-561. https://doi.org/10.1111/gcb.14486

Danielsen, F., Adrian, T., Brofeldt, S., van Noordwijk, M., Poulsen, M. K., Rahayu, S., Rutishauser, E., et al. (2013). Community monitoring for REDD+: international promises and field realities. E\&S 18. https://doi.org/10.5751/ES-05464-180341

De Vadder, F., Kovatcheva-Datchary, P., Goncalves, D., Vinera, J., Zitoun, C., Duchampt, A., Bäckhed, F., \& Mithieux, G. (2014). Microbiota-generated metabolites promote metabolic benefits via gut-brain neural circuits. Cell 156, 84-96. https://doi.org/10.1016/j.cell.2013.12.016

Diemont, S. A. W., \& Martin, J. F. (2009). Lacandon Maya ecosystem management: sustainable design for subsistence and environmental restoration. Ecol. Appl. 19, 254-266. https://doi.org/10.1890/08-0176.1

Douterlungne, D., Levy-Tacher, S. I., Golicher, D. J., \& Dañobeytia, F. R. (2008). Applying indigenous knowledge to the restoration of degraded tropical rain forest clearings dominated by bracken fern. Restoration Ecology 18, $322-329$. https://doi.org/10.1111/j.1526-100X.2008.00459.x

Durán, P., Thiergart, T., Garrido-Oter, R., Agler, M., Kemen, E., Schulze-Lefert, P., \& Hacquard, S. (2018). Microbial interkingdom interactions in roots promote arabidopsis survival. Cell 175, 973-983.e14. https://doi.org/10.1016/j.cell.2018.10.020

Dzidic, M., Boix-Amorós, A., Selma-Royo, M., Mira, A., \& Collado, M. C. (2018). Gut microbiota and mucosal immunity in the neonate. Med Sci (Basel) 6. https://doi.org/10.3390/medsci6030056

Eckert, L. E., Ban, N. C., Frid, A., \& McGreer, M. (2017). Diving back in time: Extending historical baselines for yelloweye rockfish with Indigenous knowledge. Aquatic Conserv: Mar. Freshw. Ecosyst. 28, 158-166. https://doi.org/10.1002/aqc.2834

Enright, E. F., Gahan, C. G. M., Joyce, S. A., \& Griffin, B. T. (2016). The impact of the gut microbiota on drug metabolism and clinical outcome. Yale J. Biol. Med. 89, 375-382. Retrieved from https://www.ncbi.nlm.nih.gov/pmc/articles/PMC5045146/

Erickson, C. L. (2010). The Transformation of Environment into Landscape: The Historical Ecology of Monumental Earthwork Construction in the Bolivian Amazon. Diversity (Basel) 2, 618-652. https://doi.org/10.3390/d2040619

Etchart, L. (2017). The role of indigenous peoples in combating climate change. Palgrave Commun. 3, 17085. https://doi.org/10.1057/palcomms.2017.85

Everard, M., Gupta, N., Scott, C. A., Tiwari, P. C., Joshi, B., Kataria, G., \& Kumar, S. (2018). Assessing livelihood-ecosystem interdependencies and natural resource governance in Indian villages in the Middle Himalayas. Reg. Environ. Change 1-13. https://doi.org/10.1007/s10113-018-1391-x

Fernández-Bayo, J. D., Hestmark, K. V., Claypool, J. T., Harrold, D. R., Randall, T. E., Achmon, Y., Stapleton, J. J., Simmons, C. W., \& VanderGheynst, J. S. (2019). The initial soil microbiota impacts the potential for lignocellulose degradation during soil solarization. J. Appl. Microbiol. 126, 1729-1741. https://doi.org/10.1111/jam.14258

Ficara, M., Pietrella, E., Spada, C., Della Casa Muttini, E., Lucaccioni, L., lughetti, L., \& Berardi, A. (2018). Changes of intestinal microbiota in early life. J. Matern. Fetal Neonatal Med. 1-8. https://doi.org/10.1080/14767058.2018.1506760

Fitzhugh, B., Butler, V. L., Bovy, K. M., \& Etnier, M. A. (2018). Human ecodynamics: A perspective for the study of long-term change in socioecological systems. Journal of Archaeological Science: Reports 23, $1077-1094$. https://doi.org/10.1016/j.jasrep.2018.03.016

Foin, T. C., \& Davis, W. G. (1984). Ritual and self-regulation of the Tsembaga Maring ecosystem in the New Guinea highlands. Hum. Ecol. 12, 385-412. https://doi.org/10.1007/BF01531125

Ford, A., \& Nigh, R. (2015). The Maya Forest Garden: Eight Millennia of Sustainable Cultivation of the Tropical Woodlands (New Frontiers in Historical Ecology). 1st ed. Routledge. https://doi.org/10.4324/9781315417936

Forslund, K., Hildebrand, F., Nielsen, T., Falony, G., Le Chatelier, E., Sunagawa, S., Prifti, E., Vieira-Silva, S., Gudmundsdottir, V., Pedersen, H. K., et al. (2015). Disentangling type 2 diabetes and metformin treatment signatures in the human gut microbiota. Nature 528, 262-266. https://doi.org/10.1038/nature15766

Fox, C. A., Reo, N. J., Turner, D. A., Cook, J., Dituri, F., Fessell, B., Jenkins, J., Johnson, A., Rakena, T. M., Riley, C., et al. (2017). “The river is us; the river is in our veins": re-defining river restoration in three Indigenous communities. Sustain. Sci. 12, 521-533. https://doi.org/10.1007/s11625-016-0421-1

Freeman, B. M. (2019). Promoting global health and well-being of Indigenous youth through the connection of land and culturebased activism. Glob. Health Promot. 26, 17-25. https://doi.org/10.1177/1757975919831253

Gao, X., Jia, R., Xie, L., Kuang, L., Feng, L., \& Wan, C. (2018). A study of the correlation between obesity and intestinal flora in schoolage children. Sci. Rep. 8, 14511. https://doi.org/10.1038/s41598-018-32730-6

Garibaldi, A., \& Turner, N. (2004). Cultural Keystone Species: Implications for Ecological Conservation and Restoration. Ecology and Society 9. https://doi.org/10.5751/ES-00669-090301

Garrido-Oter, R., Nakano, R. T., Dombrowski, N., Ma, K.-W., AgBiome Team, McHardy, A. C., \& Schulze-Lefert, P. (2018). Modular Traits of the Rhizobiales Root Microbiota and Their Evolutionary Relationship with Symbiotic Rhizobia. Cell Host Microbe 24, 155-167.e5. https://doi.org/10.1016/j.chom.2018.06.006

Grenni, P., Gibello, A., Barra Caracciolo, A., Fajardo, C., Nande, M., Vargas, R., ... Martín, M. (2009). A new fluorescent oligonucleotide probe for in situ detection of s-triazine-degrading Rhodococcus wratislaviensis in contaminated groundwater and soil samples. Water Res. 43, 2999-3008. https://doi.org/10.1016/j.watres.2009.04.022 
Gupta, R., Singh, A., Srivastava, M., Shanker, K., \& Pandey, R. (2019). Plant-microbe interactions endorse growth by uplifting microbial community structure of Bacopa monnieri rhizosphere under nematode stress. Microbiol. Res. 218, 87-96. https://doi.org/10.1016/j.micres.2018.10.006

Gustafsson, B. E., Daft, F. S., Mcdaniel, E. G., Smith, J. C., \& Fitzgerald, R. J. (1962). Effects of vitamin K-active compounds and intestinal microorganisms in vitamin K-deficient germfree rats. J. Nutr. 78, 461-468. https://doi.org/10.1093/jn/78.4.461

Gustafsson, B. E., Angelin, B., Einarsson, K., \& Gustafsson, J. A. (1977). Effects of cholesterol feeding on synthesis and metabolism of cholesterol and bile acids in germfree rats. J. Lipid Res. 18, 717-721. Retrieved from https://www.ncbi.nlm.nih.gov/pubmed/ 925516

Hansson, L. (2001). Traditional management of forests: plant and bird community responses to alternative restoration of oak-hazel woodland in Sweden. Biodiversity \& Conservation. https://doi.org/10.1023/A:1013125611492

Harman, G. E., \& Uphoff, N. (2019). Symbiotic Root-Endophytic Soil Microbes Improve Crop Productivity and Provide Environmental Benefits. Scientifica (Cairo) 2019, 9106395. https://doi.org/10.1155/2019/9106395

Hartoyo, A. P. P., Siregar, I. Z., Supriyanto, Prasetyo, L. B., \& Thelaide, I. (2016). Biodiversity, Carbon Stocks and Community Monitoring in Traditional Agroforestry Practices: Preliminary Results from Two Investigated Villages in Berau, East Kalimantan. Procedia Environmental Sciences 33, 376-385. https://doi.org/10.1016/j.proenv.2016.03.088

Hendgen, M., Hoppe, B., Döring, J., Friedel, M., Kauer, R., Frisch, M., Dahl, A., \& Kellner, H. (2018). Effects of different management regimes on microbial biodiversity in vineyard soils. Sci. Rep. 8, 9393. https://doi.org/10.1038/s41598-018-27743-0

Hermans, S. M., Buckley, H. L., Case, B. S., Curran-Cournane, F., Taylor, M., \& Lear, G. (2017). Bacteria as emerging indicators of soil condition. Appl. Environ. Microbiol. 83. https://doi.org/10.1128/AEM.02826-16

Hiippala, K., Jouhten, H., Ronkainen, A., Hartikainen, A., Kainulainen, V., Jalanka, J., \& Satokari, R. (2018). The potential of gut commensals in reinforcing intestinal barrier function and alleviating inflammation. Nutrients 10. https://doi.org/10.3390/nu10080988

Home, R., Bouagnimbeck, H., Ugas, R., Arbenz, M., \& Stolze, M. (2017). Participatory guarantee systems: organic certification to empower farmers and strengthen communities. Agroecology and Sustainable Food Systems 41, 526-545. https://doi.org/10.1080/21683565.2017.1279702

Horiuchi, M., Fukamachi, K., \& Oku, H. (2011). Reed community restoration projects with citizen participation: an example of the practical use of Satoyama landscape resources in Shiga Prefecture, Japan. Landscape Ecol. Eng. 7, $217-222$. https://doi.org/10.1007/s11355-010-0129-9

Hu, Y., Yang, X., Qin, J., Lu, N., Cheng, G., Wu, N., Pan, Y., Li, J., Zhu, L., Wang, X., et al. (2013). Metagenome-wide analysis of antibiotic resistance genes in a large cohort of human gut microbiota. Nat. Commun. 4, 2151. https://doi.org/10.1038/ncomms3151

Jacobson, A., Lam, L., Rajendram, M., Tamburini, F., Honeycutt, J., Pham, T., et al. (2018). A Gut Commensal-Produced Metabolite Mediates Colonization Resistance to Salmonella Infection. Cell Host Microbe 24, 296-307.e7. https://doi.org/10.1016/j.chom.2018.07.002

Jacoby, R., Peukert, M., Succurro, A., Koprivova, A., \& Kopriva, S. (2017). The Role of Soil Microorganisms in Plant Mineral NutritionCurrent Knowledge and Future Directions. Front. Plant Sci. 8, 1617. https://doi.org/10.3389/fpls.2017.01617

Jones, B. V., Begley, M., Hill, C., Gahan, C. G. M., \& Marchesi, J. R. (2008). Functional and comparative metagenomic analysis of bile salt hydrolase activity in the human gut microbiome. Proc Natl Acad Sci USA 105, $13580-13585$. https://doi.org/10.1073/pnas.0804437105

Jones, E. J., Matthews, Z. J., Gul, L., Sudhakar, P., Divekar, D., Buck, J., et al. (2018). Integrative analysis of Paneth cell proteomic data from intestinal organoids reveals functional processes affected in Crohn's disease due to autophagy impairment. DMM. https://doi.org/10.1242/dmm.037069

Jones, S. E., Pham, C. A., Zambri, M. P., McKillip, J., Carlson, E. E., \& Elliot, M. A. (2019). Streptomyces volatile compounds influence exploration and microbial community dynamics by altering iron availability. MBio 10. https://doi.org/10.1128/mBio.00171-19

Kamada, N., Chen, G. Y., Inohara, N., \& Núñez, G. (2013). Control of pathogens and pathobionts by the gut microbiota. Nat. Immunol. 14, 685-690. https://doi.org/10.1038/ni.2608

Kelbessa, W. (2013). Indigenous knowledge and its contribution to biodiversity conservation. Int. Soc. Sci. J. 64, $143-152$. https://doi.org/10.1111/issj.12038

Kennedy, P. J., Cryan, J. F., Dinan, T. G., \& Clarke, G. (2017). Kynurenine pathway metabolism and the microbiota-gut-brain axis. Neuropharmacology 112, 399-412. https://doi.org/10.1016/j.neuropharm.2016.07.002

Köberl, M., Dita, M., Martinuz, A., Staver, C., \& Berg, G. (2017). Members of Gammaproteobacteria as indicator species of healthy banana plants on Fusarium wilt-infested fields in Central America. Sci. Rep. 7, 45318. https://doi.org/10.1038/srep45318

Kong, H. G., Song, G. C., \& Ryu, C.-M. (2019). Inheritance of seed and rhizosphere microbial communities through plant-soil feedback and soil memory. Environ. Microbiol. Rep. 11, 479-486. https://doi.org/10.1111/1758-2229.12760

LaCanne, C. E., \& Lundgren, J. G. (2018). Regenerative agriculture: merging farming and natural resource conservation profitably. PeerJ 6, e4428. https://doi.org/10.7717/peerj.4428 
Laval, L., Martin, R., Natividad, J. N., Chain, F., Miquel, S., Desclée de Maredsous, C., Capronnier, S., Sokol, H., Verdu, E. F., van Hylckama Vlieg, J. E. T., et al. (2015). Lactobacillus rhamnosus CNCM I-3690 and the commensal bacterium Faecalibacterium prausnitzii A2-165 exhibit similar protective effects to induced barrier hyper-permeability in mice. Gut Microbes 6, 1-9. https://doi.org/10.4161/19490976.2014.990784

Lepofsky, D., Armstrong, C. G., Greening, S., Jackley, J., Carpenter, J., Guernsey, B., Mathews, D., \& Turner, N. J. (2017). Historical ecology of cultural keystone places of the northwest coast. Am. Anthropol. 119, 448-463. https://doi.org/10.1111/aman.12893

Liang, Y., Zhan, J., Liu, D., Luo, M., Han, J., Liu, X., Liu, C., Cheng, Z., Zhou, Z., \& Wang, P. (2019). Organophosphorus pesticide chlorpyrifos intake promotes obesity and insulin resistance through impacting gut and gut microbiota. Microbiome 7, 19. https://doi.org/10.1186/s40168-019-0635-4

Li, F., Wang, R., Hu, D., Ye, Y., Yang, W., \& Liu, H. (2014). Measurement methods and applications for beneficial and detrimental effects of ecological services. Ecological Indicators 47, 102-111. https://doi.org/10.1016/j.ecolind.2014.06.032

Li, J., Zhao, F., Wang, Y., Chen, J., Tao, J., Tian, G., Wu, S., Liu, W., Cui, Q., Geng, B., et al. (2017). Gut microbiota dysbiosis contributes to the development of hypertension. Microbiome 5, 14. https://doi.org/10.1186/s40168-016-0222-X

Li, H.-Y., Wang, H., Wang, H.-T., Xin, P.-Y., Xu, X.-H., Ma, Y., et al. (2018). The chemodiversity of paddy soil dissolved organic matter correlates with microbial community at continental scales. Microbiome 6, 187. https://doi.org/10.1186/s40168-018-0561-X

Li, L., Lin, Q., Li, X., Li, T., He, X., Li, D., \& Tao, Y. (2019). Dynamics and potential roles of abundant and rare subcommunities in the bioremediation of cadmium-contaminated paddy soil by Pseudomonas chenduensis. Appl. Microbiol. Biotechnol. https://doi.org/10.1007/s00253-019-10059-y

Lladó, S., López-Mondéjar, R., \& Baldrian, P. (2017). Forest soil bacteria: diversity, involvement in ecosystem processes, and response to global change. Microbiol. Mol. Biol. Rev. 81. https://doi.org/10.1128/MMBR.00063-16

Long, J., Tecle, A., \& Burnette, B. (2003). Cultural foundations for ecological restoration on the white mountain apache reservation. CE 8. https://doi.org/10.5751/ES-00591-080104

Lu, T., Ke, M., Lavoie, M., Jin, Y., Fan, X., Zhang, Z., et al. (2018). Rhizosphere microorganisms can influence the timing of plant flowering. Microbiome 6, 231. https://doi.org/10.1186/s40168-018-0615-0

Macharia, P. N. (2004). Community based interventions as a strategy to combat desertification in the arid and semi-arid rangelands of Kajiado District, Kenya. Environ. Monit. Assess. 99, 141-147. https://doi.org/10.1007/s10661-004-4014-6

Magnúsdóttir, S., Ravcheev, D., de Crécy-Lagard, V., \& Thiele, I. (2015). Systematic genome assessment of B-vitamin biosynthesis suggests co-operation among gut microbes. Front. Genet. 6, 148. https://doi.org/10.3389/fgene.2015.00148

Martín, J. F., \& Liras, P. (2019). Harnessing microbiota interactions to produce bioactive metabolites: communication signals and receptor proteins. Curr. Opin. Pharmacol. 48, 8-16. https://doi.org/10.1016/j.coph.2019.02.014

McVey Neufeld, K. A., Perez-Burgos, A., Mao, Y. K., Bienenstock, J., \& Kunze, W. A. (2015). The gut microbiome restores intrinsic and extrinsic nerve function in germ-free mice accompanied by changes in calbindin. Neurogastroenterol. Motil. 27, 627-636. https://doi.org/10.1111/nmo.12534

Mesa, V., Navazas, A., González-Gil, R., González, A., Weyens, N., Lauga, B., Gallego, J. L. R., Sánchez, J., \& Peláez, A. I. (2017). Use of Endophytic and Rhizosphere Bacteria to Improve Phytoremediation of Arsenic-Contaminated Industrial Soils by Autochthonous Betula celtiberica. Appl. Environ. Microbiol. 83. https://doi.org/10.1128/AEM.03411-16

Mitra, J., \& Raghu, K. (1998). Pesticides - non target plants interactions: An overview. Archives of Agronomy and Soil Science 43, 445-500. https://doi.org/10.1080/03650349809366059

Montefrio, M. J. F., \& Johnson, A. T. (2019). Politics in participatory guarantee systems for organic food production. J. Rural Stud. 65, 1-11. https://doi.org/10.1016/j.jrurstud.2018.12.014

Mörkl, S., Lackner, S., Meinitzer, A., Mangge, H., Lehofer, M., Halwachs, B., et al. (2018). Gut microbiota, dietary intakes and intestinal permeability reflected by serum zonulin in women. Eur. J. Nutr. 57, 2985-2997. https://doi.org/10.1007/s00394-0181784-0

Morrison, D. J., \& Preston, T. (2016). Formation of short chain fatty acids by the gut microbiota and their impact on human metabolism. Gut Microbes 7, 189-200. https://doi.org/10.1080/19490976.2015.1134082

Muñoz-Tamayo, R., Laroche, B., Walter, E., Doré, J., Duncan, S. H., Flint, H. J., \& Leclerc, M. (2011). Kinetic modelling of lactate utilization and butyrate production by key human colonic bacterial species. FEMS Microbiol. Ecol. 76, 615-624. https://doi.org/10.1111/j.1574-6941.2011.01085.x

Mustonen, T. (2013). Oral histories as a baseline of landscape restoration - Co-management and watershed knowledge in Jukajoki River. Fennia 76-91. https://doi.org/10.11143/7637

Neeganagwedgin, E. (2013). Ancestral Knowledges, Spirituality and Indigenous Narratives as Self-Determination. AlterNative: An International Journal of Indigenous Peoples 9, 322-334. https://doi.org/10.1177/117718011300900404

Nishida, A., Inoue, R., Inatomi, O., Bamba, S., Naito, Y., \& Andoh, A. (2018). Gut microbiota in the pathogenesis of inflammatory bowel disease. Clin. J. Gastroenterol. 11, 1-10. https://doi.org/10.1007/s12328-017-0813-5

Ohnmacht, C., Park, J.-H., Cording, S., Wing, J. B., Atarashi, K., Obata, Y., et al. (2015). MUCOSAL IMMUNOLOGY. The microbiota regulates type 2 immunity through RORyt+ T cells. Science 349, 989-993. https://doi.org/10.1126/science.aac4263 
Parada Venegas, D., De la Fuente, M. K., Landskron, G., González, M. J., Quera, R., Dijkstra, G., ... Hermoso, M. A. (2019). Short Chain Fatty Acids (SCFAs)-Mediated Gut Epithelial and Immune Regulation and Its Relevance for Inflammatory Bowel Diseases. Front. Immunol. 10, 277. https://doi.org/10.3389/fimmu.2019.00277

Pascal, V., Pozuelo, M., Borruel, N., Casellas, F., Campos, D., Santiago, A., et al. (2017). A microbial signature for Crohn's disease. Gut 66, 813-822. https://doi.org/10.1136/gutjnl-2016-313235

Paudyal, K., Baral, H., Burkhard, B., Bhandari, S. P., \& Keenan, R. J. (2015). Participatory assessment and mapping of ecosystem services in a data-poor region: Case study of community-managed forests in central Nepal. Ecosystem Services 13, 81-92. https://doi.org/10.1016/j.ecoser.2015.01.007

Pérez-Valera, E., Kyselková, M., Ahmed, E., Sladecek, F. X. J., Goberna, M., \& Elhottová, D. (2019). Native soil microorganisms hinder the soil enrichment with antibiotic resistance genes following manure applications. Sci. Rep. 9, 6760. https://doi.org/10.1038/s41598-019-42734-5

Power, A. G. (2010). Ecosystem services and agriculture: tradeoffs and synergies. Philos. Trans. R. Soc. Lond. B. Biol. Sci 365, 29592971. https://doi.org/10.1098/rstb.2010.0143

Rajasekaran, B., \& Warren, D. M. (1995). Role of indigenous soil health care practices in improving soil fertility: Evidence from South India. Journal of Soil and Water Conservation, 50(2), 146-149. Retrieved from https://www.jswconline.org/content/50/2/146

Rappaport, R. A. (1967). Ritual Regulation of Environmental Relations among a New Guinea People. Ethnology 6 , 17. https://doi.org/10.2307/3772735

Relman, D. A., \& Lipsitch, M. (2018). Microbiome as a tool and a target in the effort to address antimicrobial resistance. Proc Natl Acad Sci USA 115, 12902-12910. https://doi.org/10.1073/pnas.1717163115

Ren, Z., Li, A., Jiang, J., Zhou, L., Yu, Z., Lu, H., et al. (2019). Gut microbiome analysis as a tool towards targeted non-invasive biomarkers for early hepatocellular carcinoma. Gut 68, 1014-1023. https://doi.org/10.1136/gutjnl-2017-315084

Reyes-García, V., \& Benyei, P. (2019). Indigenous knowledge for conservation. Nat. Sustain. https://doi.org/10.1038/s41893-0190341-z

Reyes-García, V., Fernández-Llamazares, Á., McElwee, P., Molnár, Z., Öllerer, K., Wilson, S. J., \& Brondizio, E. S. (2019). The contributions of Indigenous Peoples and local communities to ecological restoration. Restor. Ecol. $27,3-8$. https://doi.org/10.1111/rec.12894

Russell-Smith, J., Yates, C. P., Edwards, A. C., Whitehead, P. J., Murphy, B. P., \& Lawes, M. J. (2015). Deriving Multiple Benefits from Carbon Market-Based Savanna Fire Management: An Australian Example. PLoS ONE 10, 00143426. https://doi.org/10.1371/journal.pone.0143426

Russell, W. R., Scobbie, L., Chesson, A., Richardson, A. J., Stewart, C. S., Duncan, S. H., Drew, J. E., \& Duthie, G. G. (2008). Antiinflammatory implications of the microbial transformation of dietary phenolic compounds. Nutr. Cancer 60, 636-642. https://doi.org/10.1080/01635580801987498

Salick, J., Ghimire, S. K., Fang, Z., Dema, S., \& Konchar, K. M. (2014). Himalayan alpine vegetation, climate change and mitigation. J. Ethnobiol. 34, 276. https://doi.org/10.2993/0278-0771-34.3.276

Sánchez, B., Delgado, S., Blanco-Míguez, A., Lourenço, A., Gueimonde, M., \& Margolles, A. (2017). Probiotics, gut microbiota, and their influence on host health and disease. Mol. Nutr. Food Res. 61. https://doi.org/10.1002/mnfr.201600240

Sangha, K. K., \& Russell-Smith, J. (2017). Towards an Indigenous Ecosystem Services Valuation Framework: A North Australian Example. Conservation and Society, 15(3), 255-269. http://www.conservationandsociety.org/article.asp?issn=0972-4923; year=2017; volume=15;issue=3; spage=255; epage=269; aulast=Sangha

Sangha, K. K., Le Brocque, A., Costanza, R., \& Cadet-James, Y. (2015). Ecosystems and indigenous well-being: An integrated framework. Global Ecology and Conservation 4, 197-206. https://doi.org/10.1016/j.gecco.2015.06.008

Sangha, K. K., Preece, L., Villarreal-Rosas, J., Kegamba, J. J., Paudyal, K., Warmenhoven, T., \& RamaKrishnan, P. S. (2018). An ecosystem services framework to evaluate indigenous and local peoples' connections with nature. Ecosystem Services 31, 111125. https://doi.org/10.1016/j.ecoser.2018.03.017

Selvam, V., Ravichandran, K. K., Gnanappazham, L., \& Navamuniyammal, M. (2003). Assessment of community-based restoration of Pichavaram mangrove wetland using remote sensing data. Current Science 85(6), 794-798. Retrieved from https://www.jstor.org/stable/24109889?seq=1

Shackleton, C. M., Ruwanza, S., Sinasson Sanni, G. K., Bennett, S., De Lacy, P., Modipa, R., Mtati, N., Sachikonye, M., \& Thondhlana, G. (2016). Unpacking pandora's box: understanding and categorising ecosystem disservices for environmental management and human wellbeing. Ecosystems 19, 587-600. https://doi.org/10.1007/s10021-015-9952-z

Shaffer, L. J. (2010). Indigenous fire use to manage savanna landscapes in southern mozambique. Fire Ecology 6, $43-59$. https://doi.org/10.4996/fireecology.0602043

Shapiro, J., \& Báldi, A. (2014). Accurate accounting: How to balance ecosystem services and disservices. Ecosystem Services 7, 201202. https://doi.org/10.1016/j.ecoser.2014.01.002

Shepard, G. H., \& Ramirez, H. (2011). "Made in Brazil”: Human Dispersal of the Brazil Nut (Bertholletia excelsa, Lecythidaceae) in Ancient Amazonia1. Econ. Bot. 65, 44-65. https://doi.org/10.1007/s12231-011-9151-6 
Simonin, M., Nunan, N., Bloor, J. M. G., Pouteau, V., \& Niboyet, A. (2017). Short-term responses and resistance of soil microbial community structure to elevated $\mathrm{CO} 2$ and $\mathrm{N}$ addition in grassland mesocosms. FEMS Microbiol. Lett. 364. https://doi.org/10.1093/femsle/fnx077

Smith, E. A., \& Macfarlane, G. T. (1996). Enumeration of human colonic bacteria producing phenolic and indolic compounds: effects of $\mathrm{pH}$, carbohydrate availability and retention time on dissimilatory aromatic amino acid metabolism. J. Appl. Bacteriol. 81, 288-302. https://doi.org/10.1111/j.1365-2672.1996.tb04331.x

Solomon, D., Lehmann, J., Fraser, J. A., Leach, M., Amanor, K., Frausin, V., ... Fairhead, J. (2016). Indigenous African soil enrichment as a climate-smart sustainable agriculture alternative. Front. Ecol. Environ. 14, 71-76. https://doi.org/10.1002/fee.1226

Spangenberg, J. H., Görg, C., Truong, D. T., Tekken, V., Bustamante, J. V., \& Settele, J. (2014). Provision of ecosystem services is determined by human agency, not ecosystem functions. Four case studies. International Journal of Biodiversity Science, Ecosystem Services \& Management 10, 40-53. https://doi.org/10.1080/21513732.2014.884166

Šrut, M., Menke, S., Höckner, M., \& Sommer, S. (2019). Earthworms and cadmium - Heavy metal resistant gut bacteria as indicators for heavy metal pollution in soils? Ecotoxicol. Environ. Saf. 171, 843-853. https://doi.org/10.1016/j.ecoenv.2018.12.102

Stagaman, K., Cepon-Robins, T. J., Liebert, M. A., Gildner, T. E., Urlacher, S. S., Madimenos, F. C., ... Bohannan, B. J. M. (2018). Market Integration Predicts Human Gut Microbiome Attributes across a Gradient of Economic Development. mSystems 3. https://doi.org/10.1128/mSystems.00122-17

Stenseke, M. (2009). Local participation in cultural landscape maintenance: Lessons from Sweden. Land use policy 26, $214-223$. https://doi.org/10.1016/j.landusepol.2008.01.005

Stepankova, R., Tonar, Z., Bartova, J., Nedorost, L., Rossman, P., Poledne, R., Schwarzer, M., \& Tlaskalova-Hogenova, H. (2010). Absence of microbiota (germ-free conditions) accelerates the atherosclerosis in ApoE-deficient mice fed standard low cholesterol diet. J. Atheroscler. Thromb. 17, 796-804. https://doi.org/10.5551/jat.3285

Storm, L., \& Shebitz, D. (2006). Evaluating the purpose, extent, and ecological restoration applications of indigenous burning practices in southwestern washington. Ecological Restoration 24, 256-268. https://doi.org/10.3368/er.24.4.256

Sudhakar, P., Jacomin, A.-C., Hautefort, I., Samavedam, S., Fatemian, K., Ari, E., et al. (2019). Targeted interplay between bacterial pathogens and host autophagy. Autophagy 15, 1620-1633. https://doi.org/10.1080/15548627.2019.1590519

Sui, J., Ji, C., Wang, X., Liu, Z., Sa, R., Hu, Y., Wang, C., Li, Q., \& Liu, X. (2019). A plant growth-promoting bacterium alters the microbial community of continuous cropping poplar trees' rhizosphere. J. Appl. Microbiol. 126, $1209-1220$. https://doi.org/10.1111/jam.14194

Sun, Y., Li, L., Xia, Y., Li, W., Wang, K., Wang, L., Miao, Y., \& Ma, S. (2019). The gut microbiota heterogeneity and assembly changes associated with the IBD. Sci. Rep. 9, 440. https://doi.org/10.1038/s41598-018-37143-Z

Tang, M.-J., Zhu, Q., Zhang, F.-M., Zhang, W., Yuan, J., Sun, K., Xu, F.-J., \& Dai, C.-C. (2019). Enhanced nitrogen and phosphorus activation with an optimized bacterial community by endophytic fungus Phomopsis liquidambari in paddy soil. Microbiol. Res. 221, 50-59. https://doi.org/10.1016/j.micres.2019.02.005

Telle-Hansen, V. H., Holven, K. B., \& Ulven, S. M. (2018). Impact of a healthy dietary pattern on gut microbiota and systemic inflammation in humans. Nutrients 10. https://doi.org/10.3390/nu10111783

Tengö, M., Brondizio, E. S., Elmqvist, T., Malmer, P., \& Spierenburg, M. (2014). Connecting diverse knowledge systems for enhanced ecosystem governance: the multiple evidence base approach. Ambio 43, 579-591. https://doi.org/10.1007/s13280-014-0501-3

Thornton, T., Deur, D., \& Kitka, H. (2015). Cultivation of Salmon and other Marine Resources on the Northwest Coast of North America. Hum. Ecol. 43, 189-199. https://doi.org/10.1007/s10745-015-9747-z

Tolhurst, G., Heffron, H., Lam, Y. S., Parker, H. E., Habib, A. M., Diakogiannaki, E., ... Gribble, F. M. (2012). Short-chain fatty acids stimulate glucagon-like peptide-1 secretion via the G-protein-coupled receptor FFAR2. Diabetes 61, 364-371. https://doi.org/10.2337/db11-1019

Tomas-Barberan, F., García-Villalba, R., Quartieri, A., Raimondi, S., Amaretti, A., Leonardi, A., \& Rossi, M. (2014). In vitro transformation of chlorogenic acid by human gut microbiota. Mol. Nutr. Food Res. 58, $1122-1131$. https://doi.org/10.1002/mnfr.201300441

Topalović, O., \& Heuer, H. (2019). Plant-Nematode Interactions Assisted by Microbes in the Rhizosphere. Curr. Issues Mol. Biol. 30, 75-88. https://doi.org/10.21775/cimb.030.075

Trauernicht, C., Brook, B. W., Murphy, B. P., Williamson, G. J., \& Bowman, D. M. J. S. (2015). Local and global pyrogeographic evidence that indigenous fire management creates pyrodiversity. Ecol. Evol. 5, 1908-1918. https://doi.org/10.1002/ece3.1494

Trivedi, P., Schenk, P. M., Wallenstein, M. D., \& Singh, B. K. (2017). Tiny Microbes, Big Yields: enhancing food crop production with biological solutions. Microb. Biotechnol. 10, 999-1003. https://doi.org/10.1111/1751-7915.12804

Tsvetkov, I., Atanassov, A., Vlahova, M., Carlier, L., Christov, N., Lefort, F., et al. (2018). Plant organic farming research - current status and opportunities for future development. Biotechnology \& Biotechnological Equipment 32, $241-260$. https://doi.org/10.1080/13102818.2018.1427509

Vannier, N., Agler, M., \& Hacquard, S. (2019). Microbiota-mediated disease resistance in plants. PLoS Pathog. 15, e1007740. https://doi.org/10.1371/journal.ppat.1007740

Van Eldere, J., Celis, P., De Pauw, G., Lesaffre, E., \& Eyssen, H. (1996). Tauroconjugation of cholic acid stimulates 7 alphadehydroxylation by fecal bacteria. Appl. Environ. Microbiol. 62, 656-661. https://doi.org/10.1128/AEM.62.2.656-661.1996 
van Riper, C. J., Landon, A. C., Kidd, S., Bitterman, P., Fitzgerald, L. A., Granek, E. F., Ibarra, S., Iwaniec, D., Raymond, C. M., \& Toledo, D. (2017). Incorporating Sociocultural Phenomena into Ecosystem-Service Valuation: The Importance of Critical Pluralism. Bioscience 67, 233-244. https://doi.org/10.1093/biosci/biw170

Villa, F., Bagstad, K. J., Voigt, B., Johnson, G. W., Athanasiadis, I. N., \& Balbi, S. (2014). The misconception of ecosystem disservices: How a catchy term may yield the wrong messages for science and society. Ecosystem Services 10, 52-53. https://doi.org/10.1016/j.ecoser.2014.09.003

Wangpakapattanawong, P., Kavinchan, N., Vaidhayakarn, C., Schmidt-Vogt, D., \& Elliott, S. (2010). Fallow to forest: Applying indigenous and scientific knowledge of swidden cultivation to tropical forest restoration. Forest Ecology and Management 260, 1399-1406. https://doi.org/10.1016/j.foreco.2010.07.042

Wang, W., Chen, L., Zhou, R., Wang, X., Song, L., Huang, S., Wang, G., \& Xia, B. (2014). Increased proportions of Bifidobacterium and the Lactobacillus group and loss of butyrate-producing bacteria in inflammatory bowel disease. J. Clin. Microbiol. 52, 398-406. https://doi.org/10.1128/JCM.01500-13

Williams, A., Kennedy, S., Philipp, F., \& Whiteman, G. (2017). Systems thinking: A review of sustainability management research. J. Clean. Prod. 148, 866-881. https://doi.org/10.1016/j.jclepro.2017.02.002

Wirbel, J., Pyl, P. T., Kartal, E., Zych, K., Kashani, A., Milanese, A., et al. (2019). Meta-analysis of fecal metagenomes reveals global microbial signatures that are specific for colorectal cancer. Nat. Med. 25, 679-689. https://doi.org/10.1038/s41591-019-0406-6

Xu, M., Li, X., Cai, X., Li, X., Christie, P., \& Zhang, J. (2017). Land use alters arbuscular mycorrhizal fungal communities and their potential role in carbon sequestration on the Tibetan Plateau. Sci. Rep. 7, 3067. https://doi.org/10.1038/s41598-017-03248-0

Yu, K., Pieterse, C. M. J., Bakker, P. A. H. M., \& Berendsen, R. L. (2019). Beneficial microbes going underground of root immunity. Plant Cell Environ. https://doi.org/10.1111/pce.13632

Zhuang, L., Chen, H., Zhang, S., Zhuang, J., Li, Q., \& Feng, Z. (2019). Intestinal microbiota in early life and its implications on childhood health. Genomics Proteomics Bioinformatics 17, 13-25. https://doi.org/10.1016/j.gpb.2018.10.002 